\title{
CELEBRATING CANADA
}

\section{Volume 2}

\section{Commemorations, Anniversaries, and National Symbols}

\author{
Edited by Raymond B. Blake and Matthew Hayday
}

Popular, government-funded anniversaries and commemorations play a significant role in shaping how we view Canada, allowing us to challenge pre-existing or dominant conceptions of our country. In Volume 2 of Celebrating Canada, editors Raymond B. Blake and Matthew Hayday continue the scholarly debate surrounding commemoration and national identity that was introduced in Volume 1 , bringing together both emerging and established scholars to examine major anniversaries in Canada's political, social, and cultural development as key moments in our collective history.

The contributors to this volume capture the multilayered meanings of belonging in the Canadian experience, investigate various attempts at shaping and reshaping identities, and explore episodes of groups resisting or participating in the identity formation process. By considering formerly marginalized viewpoints on Canada's many commemorative anniversaries, the contributors to Celebrating Canada push us to consider what these events can tell us about our history and the shifting function of nationalism.

RAYMOND B. BLAKE is professor and chair of the Department of History at the University of Regina.

MATTHEW HAYDAY is a professor in the Department of History at the University of Guelph. 
This page intentionally left blank 


\section{Celebrating Canada}

Volume 2

Commemorations, Anniversaries, and National Symbols

EDITED BY RAYMOND B. BLAKE AND MATTHEW HAYDAY

UNIVERSITY OF TORONTO PRESS Toronto Buffalo London 
(C) University of Toronto Press 2018

Toronto Buffalo London

www.utorontopress.com

Printed in Canada

ISBN 978-1-4426-4981-1 (cloth) ISBN 978-1-4426-2714-7 (paper)

Printed on acid-free, 100\% post-consumer recycled paper with vegetablebased inks.

\section{Library and Archives Canada Cataloguing in Publication}

Celebrating Canada (2018)

Celebrating Canada / edited by Raymond B. Blake and Matthew Hayday.

Includes bibliographical references and indexes.

Contents: Volume 2. Commemorations, anniversaries, and national symbols.

ISBN 978-1-4426-4981-1 (v. 2 : cloth). - ISBN 978-1-4426-2714-7 (v. 2 : paper)

1. Holidays - Canada. 2. National characteristics, Canadian.

3. Nationalism - Canada. 4. Canada - Social life and customs.

I. Blake, Raymond B. (Raymond Benjamin), editor II. Hayday,

Matthew, 1977-, editor III. Title.

GT4813.A2C434 $2018 \quad 394.26971 \quad$ C2016-905760-7

University of Toronto Press acknowledges the financial assistance to its publishing program of the Canada Council for the Arts and the Ontario Arts Council, an agency of the government of Ontario.

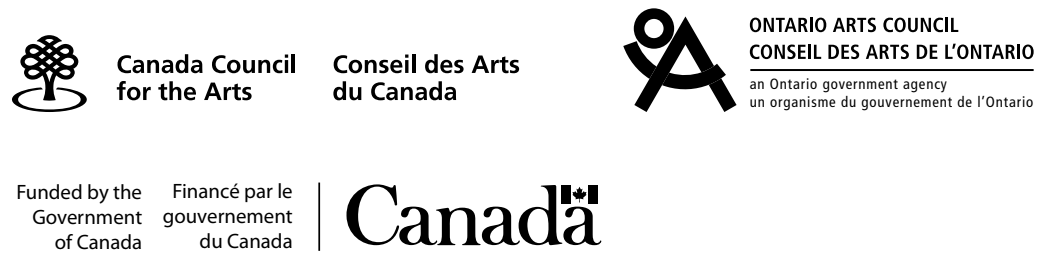

